\title{
Moving to Opportunity or
} Isolation? Network Effects of a Randomized Housing Lottery in Urban India

\section{Faculty Research Working Paper Series}

\section{Sharon Barnhardt}

Indian Institute of Management

\section{Erica Field}

Duke University

\section{Rohini Pande}

Harvard Kennedy School

\section{August 2015 \\ RWP15-043}

Visit the HKS Faculty Research Working Paper Series at:

https://research.hks.harvard.edu/publications/workingpapers/Index.aspx

The views expressed in the HKS Faculty Research Working Paper Series are those of the author(s) and do not necessarily reflect those of the John F. Kennedy School of Government or of Harvard University. Faculty Research Working Papers have not undergone formal review and approval. Such papers are included in this series to elicit feedback and to encourage debate on important public policy challenges. Copyright belongs to the author(s). Papers may be downloaded for personal use only. 


\title{
Acknowledgements
}

The authors are from the Indian Institute of Management - Ahmedabad, Duke University, and Harvard University. For Financial and field support, we thank the National Science Foundation (grant SES-0752792),

The US Department of Labor ILAB (DOL ILAB), the Centre for Microfinance (CMF) at IFMR, the Mossavar-Rahmani Center for Business and Government, the Real Estate Academic Initiative at Harvard University and the Exxon Mobil Foundation under the Closing the Global Gender Gap Initiative in Economic Participation (hosted by the Women and Public Policy Program at Harvard University).

We thank Susanna Berkouwer, Sarah Bishop, Isabelle Cohen, Manasee Desai, Janaki Kibe, Keshubhai, Marie-Pascale Grimon, Vanya Pasheva, and Divya Varma for excellent research assistance, Avdhut Fadanwis and Sachin Srivastava for data management, and DOL ILAB staff for detailed comments on an earlier draft. All errors are our own.

The views expressed herein are those of the authors and do not necessarily reflect the views of the Harvard Kennedy School or the National Bureau of Economic Research.

(C) 2015 by Sharon Barnhardt, Erica Field, and Rohini Pande. All rights reserved. Short sections of text, not to exceed two paragraphs, may be quoted without explicit permission provided that full credit, including (C) notice, is given to the source.

\begin{abstract}
A housing lottery in an Indian city provided winning slum dwellers the opportunity to move into improved housing on the city's periphery. Fourteen years later, relative to lottery losers, winners report improved housing farther from the city center, but no change in family income or human capital. Winners also report increased isolation from family and caste networks and lower access to informal insurance. We observe significant program exit: $34 \%$ of winners never moved into the subsidized housing and $32 \%$ eventually exited. Our results point to the importance of considering social networks when designing housing programs for the poor.
\end{abstract}


Across the globe, urbanization continues at a rapid pace. Between 1990 and 2011, urban population more than doubled from 1.5 to 3.6 billion, with much of this growth concentrated in the developing world. Yet, far too often the urban experience remains of poor quality - nearly a billion individuals live in urban slums typified by inadequate physical infrastructure, high population density and confined quarters - raising widespread concern that urban slums are not way-stations on the road to better living, but rather poverty traps (UN-HABITAT, 2010; Marx et al., 2013). ${ }^{1}$ Recent evidence from U.S. housing programs also emphasizes the importance of neighborhood quality (Chetty et al., 2015).

Governments throughout the developing world - including Indonesia (Some et al., 2009), China (Day and Cervero, 2010), Brazil (Dasgupta and Lall, 2009), Thailand (Viratkapan and Perera, 2006), Kenya (BBC, 2009), Nigeria (BBC, 2012) and India (studied here) - have responded with low-income housing opportunities on city peripheries (UN-HABITAT, 2003; Warah, 2004). While suburbanization offers the benefits of residential improvements and cleaner, safer environs, it entails the loss of the major advantages of urbanicity, including access to public services, short and affordable commutes, and proximity to ethnic enclaves (Lall et al., 2008). Evidence of the net value of these housing programs remains scarce mainly because those who anticipate particularly high benefits or very low costs of relocation are typically over-represented among households that opt into a suburban housing program (Field and Kremer, 2006; Bayer et al., 2008; Marx et al., 2013). It is wholly possible that, despite voluntary program take-up, the net benefits of relocating are negligible, implying low social returns to such housing programs. And absent adequate opportunity to experiment with suburban living, it is not obvious that slum dwellers who sign up for housing programs are even made weakly better off by moving.

In this paper, we provide the first experimental evidence from a developing country on the long-run impacts of a typical government housing program for slum dwellers. The program we evaluate was offered by the city government of Ahmedabad, the capital city of the Indian state of Gujarat, in partnership with the Self Employed Women's Association (SEWA), a leading trade union for poor women. The 497 program participants were informal-sector, piece-rate workers

$1 \quad$ By definition, a slum household lacks one or more of: secure tenure, durable housing, a sufficient living area of two persons or less per room, access to safe water, and access to sanitation (UN-HABITAT, 2003) 
drawn from city slums. ${ }^{2}$ Almost a quarter received the opportunity to move into improved housing in a neighborhood on the city's periphery (from now on, Colony A), roughly 7.5 miles from the center. Housing units were offered at a monthly cost well below market: the estimated subsidy per unit was more than $50 \%$ of the lease value.

The major advantage of the program we evaluate is random unit assignment via a lottery, which provides a rare source of exogenous variation in residential location akin to Moving to Opportunity (MTO) and housing voucher experiments in U.S. cities. A second advantage is our ability to evaluate relatively long-run program effects: 14 years after housing units were assigned, we successfully tracked and interviewed $89 \%$ of original lottery applicants. A third is that the nature and value of the program is very similar to India's ongoing government housing program - the Affordable Housing in Partnership scheme - which aims at constructing up to one million subsidised housing units (Ministry of Housing and Urban Poverty Alleviation, 2011). ${ }^{3}$ Finally, understanding the impact of lottery-allocated housing is, in itself, policy relevant given widespread use of lotteries to allocate subsidized low income housing in India. ${ }^{4}$

We find that, fourteen years after housing allocation, slum-dwellers who won the opportunity to relocate to objectively higher-quality housing in a safer and cleaner location were no better off on a variety of socio-economic measures than those who lost the lottery. In particular, the economic well-being of lottery winners and losers was similar in terms of current income, labor force participation, household health, and child outcomes.

Furthermore, we observe significant program exit: One-third of winners chose not to move to

$2 \quad$ These particular piece rate workers were engaged in producing unfiltered cigarettes, or beedis. Over 1.4 million Indian women are beedi workers, making it one of the largest female, informal-labor sectors (Office of the Registrar General, Census Commissioner, 2001).

3 India's first large scale housing mission - the Jawaharlal Nehru National Urban Renewal Mission (20052012) - sanctioned 1.5 million dwellings. (http://pib.nic.in/newsite/PrintRelease.aspx?relid=102645) Since the launch in 2013 of Rajiv Awas Yojana Scheme and Affordable Housing in Partnership Scheme more than 140,000 new dwellings have been sanctioned (Ministry of Housing and Urban Poverty Alleviation, 2014). Under the AHP scheme, the central government provides a subsidy of ₹75,000 per unit for municipal governments and partners to build large Affordable Housing Projects and offer the units at an affordable price to households with income below ₹100,000 (Ministry of Housing and Urban Poverty Alleviation, 2013).

4 The Scheme Guidelines for Affordable Housing in Partnership stipulate that allottees "should be made following a transparent procedure e.g. through draw of lottery preferably computerized based on detailed guidelines approved by SLSMC [State Level Sanctioning and Monitoring Committee]" (Ministry of Housing and Urban Poverty Alleviation, 2013). Other government agencies like the Delhi Development Authority (DDA) and Maharashtra Housing and Area Development Authority periodically sell flats via lottery. In 2010, the DDA received 1.1 million applications for 16,000 flats and in 2014 it again received over 1 million applications for a sale of 25,040 flats (Anand, 2014; Press Trust of India, 2014). 
Colony A. Even more surprising, a further $32 \%$ moved in but then returned to centrally located slums within ten years, forgoing the indefinite future stream of highly subsidized rent and tenure security that public housing offers. While some of those who left Colony A recovered partial value via illegal rentals, by all accounts the full private value of the apartment was unrecovered since tenure security was not transferable to an illegal occupant.

Much of the potential economic value of public housing programs in low-income settings arises from the government's ability to provide security of tenure, but this requires that participants abide by lease agreements and not revert to illegal occupancy. In the case of Colony $\mathrm{A}$, since a high fraction of winners either abandoned the unit or were delinquent on their lease agreements (or both), winners failed to gain greater tenure security. Consistent with this, we observe similar housing expenditures (net of revenues) across winners and losers, suggesting that most winners simply "gave up" the house.

The absence of socioeconomic improvement among winners, the high exit rate, and continued tenure insecurity all suggest negligible long-run economic value of this fairly expensive public program. These results are stark given that lottery participants organized the housing movement and hence represent a group of particularly motivated potential beneficiaries. Furthermore, as home-based workers, they were presumably more indifferent than most slum dwellers to residential location. Hence, our findings are arguably an upper bound on the self-targeting that a typical public housing scheme can hope to achieve.

What ultimately made most participants deem relocating to Colony A undesirable? The only negative program effects we detect are reduced ties to participants' social networks, including family. Relative to lottery losers, winners live significantly further from their adult children and see them less often. Moreover, they are less likely to know someone they can rely on for borrowing needs (6 to 9 percentage points less, depending on the item lent/borrowed) and have, on average, known such a person for nearly three fewer years, which indicates that the act of moving out of the slums severed risk-sharing ties. In qualitative interviews, movers report difficulty in maintaining network links outside of Colony A. Correspondingly, they are less likely to rely on informal insurance: losers, but not winners, report receiving informal transfers through their 
social networks in the event of a shock. Hence, geographic isolation appears to imply significant economic and social costs.

The restructuring of social networks to include links to new neighbors is also evident in the fact that winners are equally likely to rely on neighborhood networks for borrowing and lending needs. ${ }^{5}$ Within-Colony A risk-sharing arrangements, though, were likely weaker than those within city slums because they were newer and involved greater sub-caste diversity. Conversely, winners report higher neighborhood-level collective action, suggesting that geographic isolation - or the greater network closure and support it implies - enabled cooperation around local public goods. ${ }^{6}$ However, winners participated less in the city-wide Beedi Workers' Union.

Other negative effects of relocating away from the city center such as increased commuting costs and distance from school and health clinics were insignificant. Given this, we interpret program exit as reflecting the socio-economic costs of lower contact with existing network members. Consistent with this interpretation, in qualitative interviews several of those who moved into Colony A but eventually left stated that isolation proved too costly.

Ours is the first experimental evaluation of a low-income housing program in a developing country. Urban housing for the poor is a fast-emerging priority for city governments in the developing world, but there is little evidence to guide policy discussions. Our findings are consistent with housing research in the US: 10-15 years after assignment, MTO program studies find similar employment, wage, and earning patterns among program winners and losers. ${ }^{7}$ Our null findings are also consistent with other public housing opportunity studies in large North American cities (Oreopolous, 2003; Jacob, 2004; Jacob and Ludwig, 2012). In their setting, as in ours, one of the key reasons for limited program effects is the failure of households to ultimately relocate to better neighborhoods when given the opportunity. Results from our setting demonstrate that unwillingness of slum populations to relocate appears to be driven by

$5 \quad$ Within-neighborhood network ties are typically the strongest (Festinger et al., 1963; Abu-Ghazzeh, 1999; Sacerdote and Marmaros, 2006).

$6 \quad$ Greater closure implies a more interconnected network (Coleman, 1988, 1990). Jackson et al. (2012) define support as a measure of pairs of friends that have another friend in common. They find evidence from rural India that support increases with geographic proximity and is positively related to favor exchange.

7 Adult winners had better mental and physical health. Long-term child health was not affected overall, though young women report fewer health problems (Ludwig et al., 2013). Recent work does find long-run improvements in economic outcomes of children under 13 at time of relocation (Chetty et al., 2015) 
an interest in maintaining social networks, which may also explain some of the patterns found in U.S. housing programs.

To the best of our knowledge, we also provide the first long-run experimental analysis of geographic isolation on risk-sharing and informal insurance in any context. ${ }^{8}$ The idea that housing mobility programs change social networks is also evident in the MTO program: treatment households reported more college-educated friends and greater exposure to more affluent peers, but for youth there was a significant decline in the fraction who report at least one close friend, and male youth in the treatment group were less likely than those in the controls to see friends from their original neighborhood (Sanbonmatsu et al., 2011). There is no direct evidence from MTO on changes in risk-sharing capacity. ${ }^{9}$

These findings contribute a new angle to a large and growing literature on the economic benefits of urbanicity (Glaeser, 2011) that is likely to be particularly important in developing country contexts, and can help explain why slum relocation programs are so politically fraught.

The remainder of this paper proceeds as follows. Section I describes the study context, the dataset and empirical strategy. Section II examines the impact of the housing program on residential location and socio-economic well-being. We conclude this section with an analysis of the network costs of relocation. Section III concludes.

\section{Background and Data}

Below we describe the sample of slum dwellers in Ahmedabad who entered the housing lottery and the housing program, our survey design and empirical strategy.

$8 \quad$ While some non-experimental papers have noted the mixed success of slum relocation programs (Viratkapan et al., 2004), much of the focus has been on commuting costs (Takeuchi et al., 2008). An exception is Kapoor et al. (2004), who estimate models of location choice in urban India and find significant relocation costs in terms of disruption of religious and linguistic networks. There are few quantitative estimates of the significance of neighbor effects in developing countries. Montgomery and Hewett (2005) and Barnhardt (2009) are exceptions, but neither examine changes in the risk-sharing capacity of networks.

$9 \quad$ Studies with college housing arrangements have focused on social interactions extensively. Ward (2006) examines housing isolation, social networks and time investment choices among Harvard undergraduates and finds that students in a location farther from where campus life is centered participate the same amount, but invested more in local networks, which became denser. 


\section{A Slum Dwellers in Ahmedabad}

With roughly 6.4 million residents, Ahmedabad is India's sixth most populous urban area and the largest city in Gujarat, one of India's fastest-growing and most industrialized states (Office of the Registrar General, Census Commissioner, 2011). Yet, in the early 2000s the urban poverty rate in Ahmedabad was roughly 1.4 times the Indian average at 34\% (Cities Alliance, 2002). The economic mainstay of the city's poor remains informal sector employment, with women involved in home-based, piece-rate work making up a significant fraction (Unni and Rani, 2000).

Housing for the urban poor in Ahmedabad originated in the eastern half of the city near textile mills (Field et al., 2008) and was usually segregated by caste (Gillion, 1968). The decline of textile mills, which began in the 1960s and accelerated in the 1980s, significantly increased informal sector employment among these workers (Breman, 2004). Today, their living arrangements largely consist of slums that are organized along ethnic lines (Hall, 1980) and are located close to the city's commercial center (Bhatt, 2003).

\section{B The Housing Lottery}

The housing scheme we evaluate was organized by the Self Employed Women's Association (SEWA) Union, a collection of trade groups with a membership of over 500,000 women in Gujarat (SEWA, 2009). The SEWA beedi roller trade group was formed in $1978 .{ }^{10}$ Within the informal sector, the beedi industry is one of the few regulated by law - The Beedi and Cigar Workers Act (1966). As the Act provides for government housing subsidies for beedi workers, the Union advocated for a subsidized group housing program. In interviews, Union officeholders described their key motivations as reducing housing costs and improving tenure security, both of which were believed to contribute to school dropout among beedi workers' children.

In cooperation with multiple government agencies, SEWA launched a housing lottery for beedi workers in $1987 .{ }^{11}$ Union members with a monthly income of less than ₹700 (US\$11.28

10 Beedi rollers typically work at home on a piece-rate basis for agents who supply raw materials and then sell finished product to beedi companies. The pay rate in 2007 was about one dollar (₹40-42 converted into 2007 USD) for 1,000 rolled beedis (roughly one day of work).

11 SEWA's website describes their contribution: "...the Housing and Urban Development Corporation (HUDCO) [provided] loans, Ahmedabad Urban Development Authority (AUDA) [identified] a piece of land under the scheme allocating land for the economically weaker sections and [built] the houses, the Beedi 
currently) were eligible to participate, and all 497 eligible women entered the lottery. They came primarily from two caste groups, Koshti (35\%) and Padmasali (41\%), while Muslims (10\%) were the third largest group. SEWA leaders conducted the drawing of the 110 winners at a public gathering on International Housing Day in 1987.

After the lottery, the Union worked with the Ahmedabad Urban Development Authority (AUDA) to construct homes. The largest hurdle was finding suitable land. Six years later, AUDA built the houses on vacant government land situated 7.5 miles from the city center. The units were single-story rowhouses of approximately 200 square feet situated back-to-back with a narrow alley running in between.

Winners received a significant housing subsidy on Colony A units. The construction cost of a unit was ₹45,000 (Dayal, 2001), and the winner paid a initial deposit of ₹900. She then paid ₹124 (about US $\$ 2$ currently) in monthly rent. This rate was guaranteed for 20 years and was less than half the average rent reported by losers in our survey. ${ }^{12}$

\section{Data Collection}

Conducting a follow-up survey involved the daunting task of tracking participants two decades after the lottery took place. Fortunately, the official list of lottery winners - which included participant name and address in Colony A - was available through SEWA Union. We obtained the names and addresses of lottery losers from multiple sources. First, the SEWA Union office maintained a list of 297 lottery losers (out of 387 ) who had indicated an interest in entering a future housing lottery. Second, a former SEWA employee provided a participant subset list that

\footnotetext{
Workers Welfare Fund [provided] subsidies...the Gujarat Government's Ministry of Labour [sponsored] the scheme, SEWA [mobilized] the beedi workers, and SEWA Bank undertook the responsibility of collecting repayment of the loans."

12 Authors' calculations are available on request. Subleasing colony A units was forbidden but family members could occupy the residence. Failure to pay monthly rent resulted in the occupant losing the legal right to remain in the property. A unique program feature was that rent-to-own agreements with the government gave participants the opportunity to become homeowners after 20 years, but only under the unlikely scenario that all 110 winners remained in the colony and made regular monthly payments over the 20-year period. As expected, the colony failed to achieve zero delinquency/out-migration (a large fraction never even moved in), and so ultimately no one was given a title to the property and even tenants who made regular payments continue to be charged monthly rent to occupy the unit today. Since this outcome was predictable, it arguably is correct to treat the contract as a standard lease agreement.
} 
included names of an additional 26 lottery losers. ${ }^{13}$ In addition to names and addresses, this list of 109 participants also had a handful of baseline characteristics (1987 address, marital status, husband's occupation, and the incomes of the participant, husband and household) that we use in the following subsection as part of a randomization check. Finally, we undertook tracking interviews with the listed lottery participants in an attempt to identify the remaining 64 (17\%) lottery losers. Ultimately, we obtained an additional 30 names (47\% of missing) as referrals from women who were in the lottery, and their participation was verified upon contact (from now on, "referrals list"). Hence, the names of only 34 out of 387 lottery losers - or $9 \%$ of losers and $7 \%$ of all lottery participants - remain unidentified.

After constructing the participant list, we tracked and surveyed 443 participants (or a family member, in cases of death or mental illness), giving a response rate of $96 \%$ of the 463 participants who could be named ( $89 \%$ of the original 497 participants). No one refused the survey. Table I of the Online Appendix shows identical attrition rates of $4 \%$ across winners and losers drawn from the 463 listed participants, and similar rates of mortality and proxy surveying among the 443 participants found. In subsection D we provide a randomization check for our tracked and surveyed sample to show that attrition from the set of named participants and inclusion on the participant list are uncorrelated with observable characteristics.

Our survey occurred between May and October 2007, 20 years after the housing lottery and 14 years after lottery winners obtained possession of Colony A units. We asked respondents about household demographics, various socio-economic indicators, and the health, schooling, marital status, and current occupation of their children. We collected detailed data on their residential location and mobility over the last 20 years and obtained a full employment history for the participant and her husband. A neighborhood and networks module asked respondents about their social interactions with immediate neighbors and adult children, risk-sharing mechanisms (in terms of exposure to major city-level shocks in the last six years and the coping mechanisms they used to deal with them), and collective action undertaken over the last three years. We also collected GPS coordinates for participants' 1987 and 2007 residential locations.

13 In particular, two out of ten pages of the full list of all lottery participants were found by the employee. Those two pages contained 109 names, 26 of which were lottery losers not already found on the other list. 
In 2011, a real estate agent valued a subset of current lottery winner and loser residences (sampling and valuation procedure is in Section A) and we conducted qualitative fieldwork with randomly selected 21 participants from four strata: five losers, four winners who never moved into Colony A, six winners who moved into Colony A but subsequently moved out, and six winners who still lived there. We used semi-structured interviews to probe respondents on how their housing mobility opportunities affected their socioeconomic well-being and their networks.

\section{Descriptive Statistics}

Our analysis sample encompasses the 443 tracked and surveyed lottery participants. In Table I we use baseline (1987) data to provide descriptive statistics and a randomization balance check. Panel A considers participant demographics. At the time of lottery, average participant age was $28,88 \%$ were married and had, on average, 2.6 children. Beedi-rolling is a caste-based occupation, and the two main beedi-rolling castes, Padmasali and Koshti, make up over $75 \%$ of the sample. Participants typically rolled beedis at home and $12 \%$ of participants' husbands were tailors, a home-based occupation. However, close to half (46\%) of participants' husbands worked in a mill or factory located close to the city center. Participants were spread across 18 neighborhoods, with half of the women living in the inner-city neighborhoods of Amraiwadi (11\%), Bapunagar (15\%), Dhudeshwar (12\%) and Rakhial (13\%).

Panel B presents residential characteristics. To reduce data-mining concerns, we group outcomes into three thematic indices: urbanicity, property rights, and amenities. Each index is the simple average of $z$-scores for component outcomes and is balanced at baseline across treatment and control. ${ }^{14}$ The urbanicity index includes distance (in miles) from home to city center, time to walk to nearest school and time to walk to nearest hospital. The average respondent lived 2.3 miles from the city center (measured as a straight line) and a 17-minute walk to the nearest school (Online Appendix Table II).

The property rights index includes home ownership in 1987, years of home ownership prior to 1987, whether possessed an official title, and whether title was in the participant's name. Interpretations of reported ownership are ambiguous because many of the residential structures

$\overline{14}$ Online Appendix Table II reports regressions for index components. 
in city slums are illegal, and occupants frequently claim ownership absent official documentation. Sixty-three percent report that someone in their household owns the property (with average ownership being seven years) and 50\% report having documentation. Just under $10 \%$ state that the documentation is in their names.

Finally, the amenities index includes whether the 1987 house had a separate kitchen, a private toilet, and a water connection, and whether it was safe for a woman to walk in the neighborhood after $10 \mathrm{pm}$. The majority of women (84\%) claim to live in a safe neighborhood by this measure.

We also asked respondents their reasons for choosing their 1987 residence. Over 30\% report that they chose their location to be near family, and another $12 \%$ state that neighborhood resources drove their location choice. Only $3 \%$ named price as the main factor. ${ }^{15}$ For the arguably random subset list of 109 lottery applicants recovered from a former SEWA employee, we also have baseline income information, which we present in Panel C.

Comparing baseline characteristics across winners and losers shows that both household types were similar at the time of the lottery in nearly all observable dimensions. However, Muslims are over-represented in the loser category by 6.8 percentage points (Table I) ${ }^{16}$ To further investigate whether Hindus were possibly favored in the housing draw, we regressed respondent perception of whether the lottery was conducted fairly on respondent religion and find no difference across Hindu and Muslim participants (though, unsurprisingly, winners are more likely to perceive the lottery as having been fair). ${ }^{17}$ We interpret Muslim underrepresentation among the winners as a random occurrence, but do present all experimental estimates with and without a dummy indicator of participant religion or caste.

In Online Appendix Table I we further examine the balance of respondent characteristics for the participant subsample and the probability of finding households by baseline characteristics. ${ }^{18}$ Among the participant subset, winners and losers are balanced on all characteristics available in the original lottery listing, including marital status and husband's job (if married). We

15 The remaining respondents listed either "other" or "for marriage" as the main factor.

16 The p-value is 0.54 for an F-test of the joint significance of winner estimate across all 11 Table I variables. Online Appendix Table I, Panel B shows that, on marital status, home distance to city center, and husbands' occupation, winners and losers among the subset of 109 look identical to the full sample.

17 Results available upon request.

18 Found and surveyed are the same here, as the response rate among located participants was $100 \%$. 
also investigate if our tracking procedure introduced imbalances by looking for statistically significant differences in the fraction of participants found across winners and losers, conditional on individual characteristics. Only the fraction of Koshti caste participants is higher for winners (100\% found) than for losers (95\% found). For the participant subset, we observe no differences in fraction found conditional on marital status and husband's occupation (see Panel D).

\section{E Empirical Strategy}

The use of a lottery to randomly allocate the subsidized housing opportunity on the city periphery to participants allows us to cleanly identify its impact. Therefore, throughout the empirical analysis, we estimate intent-to-treat effects using the following reduced-form specification:

$$
Y_{i}=\alpha+\beta_{0} \cdot \text { winner }_{i}+X_{i} \cdot \gamma+\epsilon_{i}
$$

where $Y_{i}$ is an outcome of interest for individual $i$, and winner $_{i}$ indicates that they were offered housing in Colony A. We report estimates with and without a set of controls $X_{i}$, which includes ethnic identity indicators for whether the household is Muslim, Koshti caste, or Padmasali caste (omitting all other caste groups), a variable indicating whether the participant's name was referred by another member (rather than gathered from a Union list), and whether the participant's information was reported by proxy because she had died or was unable to answer due to mental illness.

When the unit of observation is a child, we cluster standard errors at the participant level.

\section{Results}

In Table II we examine how winning the lottery influenced subsequent residential mobility including program take-up, and Tables III to IV investigate long-term economic outcomes. In every table, each row reports the coefficient $\beta_{0}$ from regressions of the form presented in equation 1. We report estimates from regressions first without controls and with them. 


\section{A Program Take-up}

The first row of Table II reveals that, although all winners signed the lease agreement, only $66 \%$ report moving into Colony A (60 percentage points more than losers). In 2007, the average amount of time spent in Colony A was just over six years for winners (Row 2). Fourteen years after program implementation, relative to losers, only $34 \%$ of winners still lived there (Row 3 ).

Figure I plots the distribution of years spent in Colony A for the sample of winners. Approximately $60 \%$ of participants who moved in stayed on the property for at least 10 years, and $85 \%$ stayed at least five years. Hence, it is reasonable to anticipate significant relocation impacts on at least $85 \%$ of the movers, or over half of the winners. This also implies that the ITT estimates of program impact will be substantially diluted.

While low, take-up of Colony A housing exceeds that in comparable U.S. experiments, where observed lease rates among households offered location-restricted vouchers range between $19 \%$ and 48\% (Rubinowitz and Rosenbaum, 2000; Kling et al., 2007; Ludwig et al., 2012; Jacob and Ludwig, 2012). This includes a Chicago housing programs which offered previously unassisted households a significant financial gain via housing subsidies(Jacob and Ludwig, 2012). ${ }^{19}$

The subsidy value could potentially be recovered through illegal sale or lease of the unit for those who did not occupy the housing - and indeed the majority of winners who either did not move into Colony A or subsequently exited report selling or subletting their unit on the informal market. However, tenure security was not transferable, preventing full value recovery on the illegal market. Consistent with this, the magnitude of these (illegal) profits, are small and insignificant (section C).

A major program objective was to reduce the frequency of residential turnover, which was believed to constrain children's schooling attainment. In qualitative interviews, winners consistently stated that Colony A provided tenure security and permanence that rental housing on the private market lacked and most winners recognized and appreciated the subsidized rent. One winner who still lives in Colony A said: "[Tenure security] is very important. Otherwise,

$19 \quad$ Jacob and Ludwig (2012) report lower voucher take-up than in our setting despite the absence of residential location restrictions and a $\$ 369$ gain in monthly disposable income for the average participant. In Colony A, we estimate that SEWA offered units at a subsidy of at least $50 \%$ (Section B) and anecdotally the increase in tenure security was also high, although we cannot observe it precisely in our survey data. 
... the landlord could say at any time leave the house. Every year we might have had to change houses." Another said, "I was [previously] paying 500 rupees as rent in Hatkeshwar but now I only pay 124 rupees as a monthly installment."

To evaluate housing turnover, we collected data on all residences between 1987 (when they entered the lottery) and 2007 (when participants answered the survey). Table II, Row (4) shows that only $29 \%$ of participants resided in the same house at both points, and this number does not vary between winners and losers. Row (5) shows that, in part because so many winners moved into and then out of Colony A, average residential mobility is ultimately no lower among winners, with the average household reporting just over two relocations. Correspondingly, children of winners and losers report switching schools a comparable number of times (unreported).

The take-up results suggest that non-monetary costs - net of the rent received from illegal occupants - of moving from slum housing in the city center or remaining in Colony A were prohibitively large for the $66 \%$ of winners who sacrificed the stability, tenure security, and subsidized rent offered by the housing program. Given that these winners chose to participate in the lottery when the only unknown feature was exact location of the housing development, we can presume that opt-out occurred because the difference between where they expected it to be and where it was actually built greatly changed its private value.

This interpretation is further supported by the fact that, in the open-ended survey question asked of winners who left Colony A, $76 \%$ of those that provided an answer named some aspect of geographic isolation as their primary reason for leaving Colony A. ${ }^{20}$ Furthermore, $31 \%$ of these individuals list "proximity to friends and family" as the major reason for choosing their current location, relative to only $3 \%$ of those who remained in Colony A. Below we evaluate the nature of these costs that ultimately led the housing program to fail.

\section{B Urbanicity and Housing Quality}

Figures II and III show the evolution of participants' residential patterns. In 1987, winners and losers were equally concentrated in central Ahmedabad, but over the next 20 years we observe increasing sprawl. By 2007, lottery participants cover a larger geographic area with a distinct

\footnotetext{
$\overline{20}$ The answer to this question was missing in 29 cases.
} 
cluster of winners in Colony A (Figure III).

We quantify this pattern by matching the administrative ward of participants' current residences with 2001 census data. Table III, Rows (1) and (2) show that, while no less likely to have left the city, winners are significantly more likely to have left the city center for less dense suburban environs - they live in wards with roughly $30 \%$ lower population density. In Row (3) we explore this further via the urbanicity index, and again lottery winners report significantly lower urbanicity. Online Appendix Table III Panel A reports index components. Winners, on average, reside an additional mile away from the city center compared to losers, with a corresponding increase in the distance to health centers and schools. This is particularly striking given that distance to Colony A was the main predictor of program take-up among winners (unreported).

The amenities index (Table III Row 4) suggests that winners gain a 0.2 standard deviation improvement in housing amenities. ${ }^{21}$ Since winners and losers report similar value of housing improvements between 1987 and 2007 (Row 5), the difference presumably reflects higher quality housing not differential investment choices.

Consistent with this pattern, Rows (6)-(8) of Table III show differences in reported reasons for moving between 1987 and 2007. Losers more often report choosing current residence for proximity to family or friends (33\% versus $24 \%$ for winners) or local resources (29\% versus $17 \%$ ), while winners are more likely to choose residence for its price (34\% versus $9 \%$ for losers), which presumably reflects the subsidized Colony A rent. Aggregating housing data between 1987 and 2007 shows that, relative to losers, winners report living significantly fewer years in places chosen for proximity to family or amenities (Rows 9 and 10).

To monetize neighborhood and housing quality differences, in 2011 two real estate agents valued 109 houses covering $25 \%$ of losers and $22 \%$ of winners. ${ }^{22}$ Row (11) presents the mid-point of the range of assigned housing values per neighborhood as a measure of neighborhood housing quality. Consistent with the previous evidence that Colony A's geographic isolation offset

21 Winner housing had more durable walls and roof, and access to a private toilet (in Online Appendix Table III Panel B).

22 In each of five city areas that individually accounted for at least $5 \%$ of surveyed participants, we selected neighborhoods with at least three participants and valued participant homes. In Colony A, instead of valuing all nearly-identical homes, we valued $20 \%$ of the homes inhabited by lottery participants. This implied a slightly lower winner proportion in the sample. 
economic gains of higher value housing, we observe similar housing prices across neighborhoods where winners reside and where losers reside.

\section{Economic Well-being}

Table IV examines measures of economic well-being. Fourteen years after obtaining possession of Colony A housing, we observe strikingly few differences between lottery winners and losers, including key characteristics that have the potential to be influenced by residential location. Panel A, Row (1) shows that winning the lottery leaves the adult labor supply index unaffected. (Online Appendix Table III reports index components.) On average, participants and their husbands work 40 hours per week, and the only observable difference is that winners are less likely to hold a second job (though the incidence of a second job is very low). We also do not observe differences on labor supply cost index. Reflecting the labor supply patterns, total and individual household members' labor incomes are virtually identical across groups (Panel A), with no visible difference in patterns of consumption, savings, or borrowing (Online Appendix Table IV).

While the absence of employment effects on participants may reflect the home-based nature of work, the absence of employment effects for husbands is more surprising given increased distance from the city center. The latter is suggestive of those with job opportunities in the city moving out of or failing to move into Colony A. In our qualitative interviews women typically stated that, while fixed beedi rates meant that moving to Colony A left their own earnings unchanged, the lack of nearby low-skilled local jobs and the resulting increase in commuting costs affected husband and children. One resident who left Colony A after three years said:

[My husband] was working at a public distribution system shop that was in Rakhial. He continued working there, in the same shop, even after we moved to Colony A. He used to ride his bicycle to work - it would take him one hour to get there. The commute was very difficult for him...Sometimes he would fall sick from exhaustion.

Winners and losers also report similar housing expenses and income between 1993 and 2007, despite the highly subsidized rent in Colony A and the fact that several winners rented out or 
sold their homes. We calculate housing costs net of income as the sum of monthly rent paid minus any income made from the lease or sale of property over the period. The point estimates indicate a small reduction in housing costs from winning the lottery, which primarily comes from a non-trivial increase in income from the sale or lease of housing either inside or outside Colony A that is offset by a small increase in monthly rent over the 14-year period (Table IV, Panel A). ${ }^{23}$

Likewise, after 14 years lottery winners and losers report similar wealth and well-being. The Asset Index values are virtually identical, as are demographics and adult and child human capital investment. Panel B shows that winners and losers face similar post-lottery fertility patterns and we also observe similar health outcomes across the two groups. Levels of educational attainment for children are similar in winner and loser households (7.5 years of schooling, on average), and both groups report similar school transportation costs.

Nonetheless, the qualitative data points to some adverse impacts for winners that led to program exit. A poignant example was offered by a winner who moved out after a few years" $" M y$ son got sick and had a very high fever which reached his brain. There were no medical facilities or proper doctors in Colony A who could help him. So, we decided to move to Bapunagar. Since then we have not been living in Colony A." Likewise, said the winner whose husband had to commute too far in Colony A: "The children were always getting sick. It was too tiring...In [our old neighborhood] Rakhial, schools and markets were all much closer. In Colony A everything was far away - taking the children to school took half an hour." The absence of adverse human capital effects on average despite the fact that half of winners spent a significant amount of time in Colony A indicates that those who would have been negatively impacted by the move exited Colony A relatively quickly.

Tenure security was also unaffected. In terms of home-ownership rates, ultimately none of the winners managed to purchase their home in Colony A by the end of the lease period (2013),

$23 \quad$ Increase in winners' rental and sales income comes both from leasing or selling properties where they resided prior to the lottery, and from the illegal sale or lease of their Colony A unit. As of 2007, $15 \%$ of lottery winners report renting out the Colony A unit and $34 \%$ had illegally sold it. While Colony A rent was lower than average rental cost of units outside of Colony A, a significant number of those outside of Colony A report not paying rent at some point.

24 Regression estimates show that winners live farther from health facilities. 
so the program failed to increase rates of home ownership. ${ }^{25}$ Furthermore, while in theory public housing offers high tenure security through a standard lease arrangement, since two-thirds of the units were being occupied illegally at follow up, and the vast majority of winners still occupying their units were no longer making regular lease payments (both of which are grounds for losing occupancy rights in public housing), tenure security in Colony A was ultimately no stronger than that of illegal settlements in the slums. ${ }^{26}$

\section{Social Capital}

Low program take-up and high program exit suggests that costs outweighed potential program benefits, and our analysis and interviews suggest that these costs were linked to geographic isolation. Since a key consequence of geographic isolation is reduced social ties, we next examine how relocation influenced participants' social networks and access to informal insurance.

\section{D.1 Informal Insurance}

To examine the borrowing and lending value of social networks, we consider four questions concerning whom participants borrow from and to whom they lend various items. ${ }^{27}$

Among losers, $93 \%$ belong to one or more borrowing/lending networks (Table V). This number is nearly 10 percentage points lower for winners, and winners also report knowing such a person for three fewer years. Consistent with the interpretation that relocation to Colony A severed network ties, among those with network links, Online Appendix Table V Panel A shows that the person winners and losers are as likely to depend on (or support) the most belongs to the same neighborhood $(63 \%)$, implying that relocation led winners to reorganize their borrowing networks. Table V Row (4) shows that insurance networks, for both winners and losers, most often (66\%) consist of members from the same caste, suggesting that both

$\overline{25} \quad$ A significant fraction of both occupants and non-occupants stopped making monthly installments prior to completing the lease agreement, such that the opportunity for ownership was forfeited by all.

26 Administrative data from the bank indicate that ultimately only 11 winners occupied and made regular lease payments on their unit.

27 The four questions are: Who is the person you trust enough to lend ₹50 for 24 hours? Who is the person you would ask to borrow ₹50 from for 24 hours? Who is the person you would go to if you needed to borrow kerosene or rice for one day? In case of a health emergency, whom would you go to for borrowing ₹500? Online Appendix Table II presents regressions estimating these borrowing and lending outcomes individually. 
location and community matter.

Data on transfers in the event of shocks provides direct evidence regarding informal insurance. In the six years preceding our survey Ahmedabad experienced several city-wide shocks including an earthquake in 2001, communal riots in 2002, and a viral epidemic (chikungunya) in 2006. Ninety-six percent of respondents report personal damages (on average 30 days of work lost per event) from at least one of these events and the likelihood, number, and severity (in terms of work days lost) is similar across winners and losers (Online Appendix Table V, Panel F).

Risk-sharing in response to these shocks is very limited, and - consistent with the evidence from hypothetical questions about availability of informal insurance - the incidence is significantly lower among lottery winners. Lottery losers report receiving an average of ₹71 (Table V, Row 2) in informal transfers in the event of a shock while lottery winners report no informal help. Thus, in both real and hypothetical scenarios, winners rely less on friends and family for help in the event of shocks.

All three types of shocks - natural disasters, riots and disease epidemics - are geographically concentrated and likely to hit a large fraction of network members simultaneously. This may also contribute to why lottery winners - or those who are much more likely to have relocated to Colony A - have weak informal insurance networks. If their networks are more locally dense and geographically isolated, then their ability to share risks might be particularly compromised. ${ }^{28}$

\section{D.2 Social Interaction}

To understand the potential mechanisms through which informal insurance provision is lower in the suburbs, Panel B of Table V reports experimental estimates of the effect of winning the housing lottery on social interactions. We first look at family interaction. In Row (1) of Panel $\mathrm{B}$ we see that adult children on average live significantly farther away from lottery participants (non-resident children live an average of 1.3 miles away among lottery winners and 0.7 miles away among lottery losers). As seen in Row (2), distance between mothers and children results

28 An alternative explanation is that winners have greater access to formal insurance, but this is not supported by survey data: $9 \%$ of losers received help from the government, an NGO or a religious organization following a shock, and among winners this fraction is lower by 6 percentage points without controls $(\mathrm{p}<.05)$ and by 4 percentage points $(\mathrm{p}<.1$ ) with controls (Online Appendix Table V, Panel F). 
in less frequent interaction. Winners are $5 \%$ less likely see an adult child at least monthly.

This pattern is consistent with the idea that greater average distances to employment opportunities and neighborhood resources discourage adult children from staying in their parents' neighborhood. Indeed, the fact that adult sons' contribution to household income is comparable across winners and losers suggests that they are sacrificing geographic proximity to the family in order to maintain steady income and employment.

Social isolation from immediate family members is a key relocation cost for winners. That said, we observe a compensating increase in social interaction with neighbors. Our survey asked respondents about socialization (via conversation, drinking tea together, or sharing a meal) with four neighboring households (left, right, across and behind their houses). The average respondent has 2.7 immediate neighbors, and this number is comparable across winners and losers (not shown). We estimate regressions where the unit of observation is defined as a respondentneighbor pair and cluster standard errors by respondent.

Interaction with immediate neighbors is high, and significantly more for those encouraged to relocate: $95 \%$ of pairs have socialized and this number is 3 percentage points higher for winners. This is striking given that Colony A neighbors are $24 \%$ less likely to be from the same caste (Panel B, Row 4). Geographic isolation and greater occupational homogeneity (Panel B, Row 5) are strong countervailing forces encouraging neighbor interaction.

These patterns help explain lower risk-sharing capacity among neighbors in Colony A. First, less connectedness (by virtue of being more likely to belong to a different caste and having known one another for less time) could lower their ability to maintain otherwise optimal insurance agreements. Second, they are more likely to share the same occupation and so are more subject to correlated income shocks.

In qualitative interviews, as well, several respondents described the social costs of geographic isolation. Poor transportation and the low prevalence of mobile phones in the 1990s increased the sense of isolation from the caste network. Many respondents who subsequently moved out reported feeling "scared" and "lonely" - especially since their husbands worked long hours in the city. The husband of one winner who left Colony A started his comments by saying, "The 
whole area was deserted and lonely - you could die there and no one would know it." The fact that moving to Colony A increased distance from their relatives heightened the sense of loneliness, and left many feeling socially disjunct from their community (caste) and family. He continued, "When we were living in Colony A we were very cut off from everyone. No one was inviting us to any functions."

In contrast, losers described their main network as caste-based. One loser who lives east of the old city explained, "There is a sense of community here - but it is along caste lines. People from our caste help us, but not others."

\section{D.3 Collective Action}

In Panel $\mathrm{C}$ we turn to collective action. Each respondent was asked about her participation in activities to benefit the community over the last three years. ${ }^{29}$ Nineteen percent of losers report contributing to community public goods over the last three years, and this percentage almost doubles among winners.

Winners' higher propensity to cooperate with neighbors may be the flip side of reduced risk-sharing: denser local networks can facilitate cooperation around public goods with highly localized benefits. Put differently, public goods that only benefit those living nearby may be easier to provide when networks are geographically concentrated. ${ }^{30}$ The most common public goods provided were precisely of this nature: gutters, road maintenance, temples, and local celebrations. In addition, $91 \%$ of community public goods involved contributions from all or most members of the community. It is likely that such unanimity is harder to achieve in more diffuse networks. ${ }^{31}$

Finally, we collected information on city-wide collective action - specifically, participation in the beedi worker union that all participants belonged to at the time of the lottery. Twenty

29 The specific question asked was, "What activities or problems have you worked on with your neighbors to benefit the community in the past three years?" The most common answers were: nothing, gutters, something for temple or mosque, wedding for a neighbor, funeral for a neighbor.

30 Reasons include (i) individuals may value a given public good more if a higher fraction of her network members benefit from that good, and (ii) enforcing informal agreements to contribute may be easier when more beneficiaries can monitor and punish a potential beneficiary.

31 For example, the likelihood that one of the potential beneficiaries is unconnected to others in the network is greater if networks are less dense, so it will be harder to enforce that individual's contribution to the project. 
years later, unionization rates are similar across winners and losers (86\% and 88\%, respectively). However, while $47 \%$ of losers report having attended a union meeting during the previous year, this number is 18 percentage points lower among winners.

Overall, the patterns suggest that, likely due to geographic isolation, winners invested less in collective action across neighborhoods and maintaining social ties with the broader community of beedi workers and substituted toward less costly local ties. Unfortunately, the high degree of spatial correlation in the major economic shocks such as floods, earthquakes, and riots, rendered these more localized networks less valuable in terms of providing informal insurance.

\section{E Mobility versus Income Effects}

Thus far we have interpreted the ITT results (changes in social interactions, informal insurance and collective action) as being driven by program compliers - specifically, the two-thirds of winners who moved to Colony A, and in some instances, by the one-third of winners who still live there. However, it is possible that some of the patterns reflect changes in long-run outcomes experienced by non-movers via the income effect associated with selling or renting subsidized housing. Distinguishing between these two possibilities is important for extrapolating our results to settings with different compliance rates, or where enforcement of lease agreements is possible.

Since the set of movers are clearly a non-random sample of winners, it is difficult to rigorously establish that program effects are disproportionately concentrated among them. However, three facts point to this being the case. First, as shown in Table 6, in regressions run on only the winner sample, in which outcomes are regressed on indicators of whether the respondent ever moved to Colony A and whether the respondent still lives in Colony A, all of the significant ITT program effects are concentrated among the subset of movers, and in many cases only among current Colony A residents. In these regressions, the coefficient estimate on a dummy indicator of having moved to Colony A generates a point estimate that is significantly larger if not more statistically significant than we observe in the ITT analysis, although we cannot rule out that movers are ex ante different than non-movers in these dimensions. ${ }^{32}$

$\overline{32}$ The only exception is Panel C Row (1). Winners report more borrowing contacts, but these contacts are also less likely to belong to the same caste and may, therefore, be less valuable. 
Second, the estimated magnitudes of the ITT program effects are small enough to justify effect sizes up to three times as large (if concentrated among Colony A residents). For instance, it is plausible that distance to non-co-resident children increases from 2 to 5.5 miles. In fact, if only one third of them live at home, and the rest return to the city center - which is 7.5 miles from Colony A - then our ITT estimate makes sense.

Third, given that we in general find only negative effects of the program, it is unlikely that income effects are responsible for the patterns. For instance, there is no clear reason that a modest positive income shock would cause adult children to live farther away from their parents, or reduce ability to rely on network members for help.

\section{Conclusion}

Even among a group of slum dwellers who lobbied hard for the opportunity to move into public housing outside of the slums, ultimately very few found it optimal to leave the city center. Fourteen years after housing assignment, only $34 \%$ remained in public housing and the majority had returned to the slums. Evidence from other housing mobility programs suggests that the Colony A program was not an outlier. For instance, a survey we conducted in 2007 of participants in another housing program in Ahmedabad (where beneficiaries were again chosen by lottery) showed that only $46 \%$ of winners or their relatives were living in the unit they won just two and a half years after winning it.

The main policy lesson is that it is very hard to make public housing relocation programs sufficiently attractive for the poor in developing countries to opt in, so this may rarely be the optimal policy response to housing concerns of slum populations. While we cannot rule out the possibility that reductions in labor income or schooling access played a role in program exit, a major constraint appears to be the severance of social ties and the resulting loss of informal insurance that accompanied relocation, which was too costly to make even highly subsidized public housing in the suburbs worthwhile for most participants in our setting.

While policy-makers typically acknowledge costs of relocation programs such as increased commuting times or distance to health and education facilities, such costs can in theory be 
remedied with better public transportation or targeted suburban infrastructure. The destruction of social capital that comes from reshuffling slum households is a welfare loss that cannot be so easily rebuilt. Although new ties may be formed eventually, slum relocation programs as they are normally envisioned destroy economically valuable social capital by severing links that may have evolved and strengthened in the neighborhood over decades and that likely result from the optimal sorting of individuals into enclaves.

Our findings suggest that alternative policies such as neighborhood-wide relocation programs may be more appropriate for slum-dwellers. Alternatively, slum upgrading programs that do not try to move people at all may be a less wasteful approach to public housing policy in developing countries. 


\section{References}

Abu-Ghazzeh, T. M. (1999). Housing Layout, Social Interaction, and the Place of Contact in Abu-Nuseir, Jordan. Journal of Environmental Psychology XIX, 41-73.

Anand, S. (2014). Delhi's DDA House 'Lottery': What to Know. September 1. http://tinyurl. com/odhgkv5 [Accessed: June 28, 2015].

Barnhardt, S. (2009). Near and Dear: Evaluating the Impact of Neighbor Diversity on InterReligious Attitudes. Ph. D. thesis, Harvard University.

Bayer, P., S. L. Ross, and G. Topa (2008). Place of work and place of residence: Informal hiring networks and labor market outcomes. Journal of Political Economy 116(6), 1150-1196.

BBC (2009). Kenya begins huge slum clearance. September 16. http://news.bbc.co.uk/2/ hi/africa/8258417.stm [Accessed: June 29, 2015].

BBC (2012). Lagos Makoko slums knocked down in Nigeria. July 17. http://www.bbc.com/ news/world-africa-18870511 [Accessed: June 29, 2015].

Bhatt, M. R. (2003). Understanding slums: Case studies for the global report on human settlements 2003: The case of ahmedabad, india.

Breman, J. (2004). The making and unmaking of an industrial working class: sliding down the labour hierarchy in Ahmedabad, India. Amsterdam: Amsterdam University Press.

Chetty, R., N. Hendren, and L. F. Katz (2015). The Effects of Exposure to Better Neighborhoods on Children: New Evidence from the Moving to Opportunity Experiment. Technical report, National Bureau of Economic Research.

Cities Alliance (2002). Sewa banks housing microfinance program in india. Shelter Finance for the Poor Series 4 iii.

Coleman, J. (1990). Foundations of Social Theory. Cambridge, MA: Belknap. 
Coleman, J. S. (1988). Social Capital in the Creation of Human Capital. American Journal of Sociology 94, S95-S120.

Dasgupta, B. and S. V. Lall (2009). Assessing benefits of slum upgrading programs in secondbest settings. In S. V. Lall (Ed.), Urban Land Markets: Improving Land Management for Successful Urbanization. Springer.

Day, J. and R. Cervero (2010). Effects of residential relocation on household and commuting expenditures in Shanghai, China. International journal of urban and regional research $34(4)$, $762-788$.

Dayal, M. (2001). Towards Securer Lives: SEWA's Social-security Programme. Orient Blackswan.

Festinger, L., S. Schachter, and K. Back (1963). Social Pressures in Informal Groups: A Study Of Human Factors in Housing. Stanford, CA: Stanford University Press.

Field, E., M. Levinson, R. Pande, and S. Visaria (2008). Segregation, Rent Control, and Riots: The Economics of Religious Conflict in an Indian City. American Economic Review 98, $505-510$.

Field, E. M. and M. Kremer (2006). Impact evaluation for slum upgrading interventions, Volume 3. World Bank, Poverty Reduction and Economic Management, Thematic Group on Poverty Analysis, Monitoring and Impact Evaluation.

Gillion, K. (1968). Ahmedabad; a Study in Indian Urban History. University of California Press.

Glaeser, E. (2011). Triumph of the City:How Our Greatest Invention Makes Us Richer, Smarter, Greener, Healthier, and Happier. Penguin Press.

Hall, D. (1980). A spatial analysis of urban community development policy in India, Volume 1. New York: Research Studies Press Ltd.

Jackson, M. O., T. Rodriguez-Barraquer, and X. Tan (2012). Social capital and social quilts: Network patterns of favor exchange. The American Economic Review, 1857-1897. 
Jacob, B. (2004). Public Housing Vouchers and Student Achievement: Evidence from Public Housing Demolitions in Chicago. American Economic Review 94, 233-258.

Jacob, B. and J. Ludwig (2012). The Effects of Housing Assistance on Labor Supply: Evidence from a Voucher Lottery. The American Economic Review 102.

Kapoor, M., S. Lall, M. Lundberg, and Z. Shalizi (2004). Location and Welfare in Cities: Impacts of Policy Interventions on the Urban Poor. World Bank Policy Research Working Paper (No. 3318).

Kling, J., J. B. Liebman, and L. F.Katz (2007). Experimental Analysis of Neighborhood Effects. Econometrica 75, 83-119.

Lall, S. V., M. K. Lundberg, and Z. Shalizi (2008). Implications of alternate policies on welfare of slum dwellers: evidence from Pune, India. Journal of Urban Economics 63(1), 56-73.

Ludwig, J., G. J. Duncan, L. A. Gennetian, L. F. Katz, R. C. Kessler, J. R. Kling, and L. Sanbonmatsu (2012). Neighborhood effects on the long-term well-being of low-income adults. Science 337(6101), 1505-1510.

Ludwig, J., G. J. Duncan, L. A. Gennetian, L. F. Katz, R. C. Kessler, J. R. Kling, and L. Sanbonmatsu (2013). Long-term neighborhood effects on low-income families: Evidence from moving to opportunity. The American Economic Review 103(3), 226-31.

Marx, B., T. Stoker, and T. Suri (2013). The Economics of Slums in the Developing World. Journal of Economic Perspectives 27(4), 187-210.

Ministry of Housing and Urban Poverty Alleviation (2011). Toward more inclusive cities... http: //mhupa.gov.in/ray/01-MoHUPA-Brochure-20English.pdf [Accessed: June 30, 2015].

Ministry of Housing and Urban Poverty Alleviation (2013). Affordable Housing in Partnership: Scheme Guidelines. http://mhupa.gov.in/W_new/AHP_23_09_2013.pdf [Accessed: June 30, 2015]. 
Montgomery, M. and P. Hewett (2005). Urban Poverty and Health in Developing Countries: Household and Neighborhood Effects. Demography 87(42), 397-425.

Office of the Registrar General, Census Commissioner (2001). Census of India. New Delhi: Government of India.

Office of the Registrar General, Census Commissioner (2011). Rural-urban distribution. In Provisional Population Totals, Paper 2, Volume 1. New Delhi: Government of India.

Oreopolous, P. (2003). The Long-Run Consequences of Living in a Poor Neighborhood. Quarterly Journal of Economics 118, 1533-1575.

Press Trust of India (2014). DDA Housing Scheme: Unsuccessful Applicants May Get Refund by December 24. December 17. http://tinyurl.com/pw7p7yt [Accessed: June 28, 2015].

Rubinowitz, L. S. and J. E. Rosenbaum (2000). Crossing the Class and Color Lines: From Public Housing to White Suburbia. Chicago: University of Chicago Press.

Sacerdote, B. and D. Marmaros (2006). How Do Friendships Form? Quarterly Journal of Economics 121(1), 79-119.

Sanbonmatsu, L., J. Ludwig, L. Katz, L. Gennetian, G. Duncan, R. Kessler, E. Adam, T. McDade, and S. T. Lindau (2011). Moving to Opportunity for Fair Housing Demonstration Program. Final Impacts Evaluation. U.S. Department of Housing and Urban Development, Office of Policy Development and Research.

SEWA (2009). SEWA's structure. http://www . sewa.org/About_Us_Structure. asp [Accessed: June 29, 2015].

Some, W., W. Hafidz, and G. Sauter (2009). Renovation not relocation: the work of Paguyuban Warga Strenkali (PWS) in Indonesia. Environment and Urbanization 21(2), 463-475.

Takeuchi, A., M. Cropper, and A. Bento (2008). Measuring the welfare effects of slum improvement programs: The case of Mumbai. Journal of Urban Economics 64, 65-84. 
UN-HABITAT (2003). The challenge of slums: global report on human settlements 2003. London: Earthscan.

UN-HABITAT (2010). State of the World's Cities 2010/2011 - Cities for All: Bridging the Urban Divide. Nairobi: United Nations Human Settlements Programme.

Unni, J. and U. Rani (2000). Urban informal sector: Size and income generation processes in Gujarat. National Council of Applied Economic Research Reports. (2).

Viratkapan, V. and R. Perera (2006). Slum relocation projects in Bangkok: what has contributed to their success or failure? Habitat International 30(1), 157-174.

Viratkapan, V., R. Perera, and S. Watanabe (2004). Factors contributing to the development performance of slum relocation projects in Bangkok, Thailand. International Development Planning Review 26(3), 231-260.

Warah, R. (2004). Slums and Housing in Africa. UN Chronicle 40(4), 19, 28.

Ward, B. A. (2006). Essays on the Economics of Social Interaction. Ph. D. thesis, Harvard University. 
Table I: Baseline (1987) Characteristics

\begin{tabular}{|c|c|c|c|}
\hline & Winner & Non-Winner Mean & $\mathrm{N}$ \\
\hline \multicolumn{4}{|l|}{ Panel A - Demographics } \\
\hline \multirow[t]{2}{*}{ Age } & 1.06 & 28.21 & 430 \\
\hline & $(1.14)$ & {$[9.95]$} & \\
\hline \multirow[t]{2}{*}{ Muslim } & $-0.07^{* *}$ & 0.12 & 443 \\
\hline & $(0.03)$ & {$[0.32]$} & \\
\hline \multirow[t]{2}{*}{ Padmasali Caste } & 0.07 & 0.39 & 443 \\
\hline & $(0.06)$ & {$[0.49]$} & \\
\hline \multirow[t]{2}{*}{ Koshti Caste } & -0.04 & 0.37 & 443 \\
\hline & $(0.05)$ & {$[0.48]$} & \\
\hline \multirow[t]{2}{*}{ Married } & -0.05 & 0.88 & 443 \\
\hline & $(0.04)$ & {$[0.33]$} & \\
\hline \multirow{2}{*}{ Widowed, divorced, or separated } & 0.04 & 0.09 & 443 \\
\hline & $(0.04)$ & {$[0.28]$} & \\
\hline \multirow[t]{2}{*}{ Number children born } & -0.02 & 2.58 & 443 \\
\hline & $(0.25)$ & {$[2.17]$} & \\
\hline \multirow[t]{2}{*}{ Husband is employed } & -0.04 & 0.99 & 344 \\
\hline & $(0.03)$ & {$[0.11]$} & \\
\hline \multirow[t]{2}{*}{ Husband had a mill or factory job } & 0.09 & 0.49 & 344 \\
\hline & $(0.06)$ & {$[0.50]$} & \\
\hline \multirow[t]{2}{*}{ Husband had a tailoring job } & -0.05 & 0.13 & 344 \\
\hline & $(0.04)$ & {$[0.34]$} & \\
\hline \multicolumn{4}{|l|}{ Panel B - Residences } \\
\hline \multirow[t]{2}{*}{ Urbanicity Index } & 0.06 & -0.01 & 443 \\
\hline & $(0.07)$ & {$[0.65]$} & \\
\hline \multirow[t]{2}{*}{ Property Rights Index } & -0.01 & -0.01 & 443 \\
\hline & $(0.08)$ & {$[0.75]$} & \\
\hline \multirow[t]{2}{*}{ Amenities Index } & -0.05 & 0.00 & 427 \\
\hline & $(0.07)$ & {$[0.63]$} & \\
\hline \multirow[t]{2}{*}{ Chose location to be near family or friends } & 0.06 & 0.30 & 443 \\
\hline & $(0.05)$ & {$[0.46]$} & \\
\hline \multirow[t]{2}{*}{ Chose location for resources } & -0.01 & 0.12 & 443 \\
\hline & $(0.04)$ & {$[0.33]$} & \\
\hline \multirow[t]{2}{*}{ Chose location for price } & 0.01 & 0.03 & 443 \\
\hline & $(0.02)$ & {$[0.18]$} & \\
\hline \multicolumn{4}{|l|}{ Panel C - Income (subset) } \\
\hline \multirow[t]{2}{*}{ Participant's Income (INR per month) } & -15.65 & 268.15 & 109 \\
\hline & $(19.75)$ & {$[108.28]$} & \\
\hline \multirow[t]{2}{*}{ Husband's Income (INR per month) } & 43.65 & 334.31 & 109 \\
\hline & $(39.10)$ & {$[203.91]$} & \\
\hline
\end{tabular}

1. Each row of the Winner column reports the coefficient from an OLS regression where the explanatory variable is whether the respondent won the lottery.

Robust SE in ( ), standard deviations in [ ]. ${ }^{*} p<0.10,{ }^{* *} p<0.05,{ }^{* * *} p<0.01$

2. Sample size less than 443 is due to missing observations, except for Panel A variables for husband since only 366 participants were married in 1987 and for Panel C, which is for the participant subset.

3. The Urbanicity Index consists of miles from house to city center, minutes walking to nearest hospital and school.

4. The Property Rights Index consists of whether they owned their home in 1987, how many years pre-1987 they owned their home, whether they owned the title and whether title was in the participant's name.

A participant owns a house if someone in their household owns the house.

5. The Amenities Index consists of whether the participant: could walk outside at night up to 10 PM, had a private toilet, a separate kitchen, and water tap in the house. 
Table II: Program Take-up

\begin{tabular}{lcccc}
\hline \hline & \multicolumn{2}{c}{ Winner } & Non-winner & $\mathrm{N}$ \\
& No Controls & With Controls & Mean & \\
\hline Respondent's family ever lived in Colony A & $0.60^{* * *}$ & $0.60^{* * *}$ & 0.06 & 443 \\
& $(0.05)$ & $(0.05)$ & {$[0.24]$} & \\
Years respondent lived in Colony A & $6.08^{* * *}$ & $6.03^{* * *}$ & 0.39 & 443 \\
& $(0.59)$ & $(0.60)$ & {$[1.99]$} & \\
Respondent's family lives in Colony A & $0.28^{* * *}$ & $0.28^{* * *}$ & 0.06 & 443 \\
& $(0.05)$ & $(0.05)$ & {$[0.24]$} & \\
Lives in same house as before lottery & -0.07 & -0.05 & 0.29 & 443 \\
& $(0.05)$ & $(0.05)$ & {$[0.45]$} & \multirow{2}{*}{443} \\
Number of houses lived in since 1987 & 0.02 & -0.00 & 2.16 & \\
\hline \hline
\end{tabular}

1. Each row of Winner columns reports the coefficient from an OLS regression where the explanatory variable is whether the respondent won the lottery. Robust SE in ( ), standard deviations in [ ]. ${ }^{*} p<0.10,{ }^{* *} p<0.05,{ }^{* * *} p<0.01$

2. The set of controls comprises individual indicator variables for whether participant is Muslim, Koshti caste or Padmasali caste (other castes omitted), whether participant was identified by referral, and whether a familymember responded to the survey. 
Table III: Current Housing and Neighborhood Quality

\begin{tabular}{lcccc}
\hline \hline & \multicolumn{2}{c}{ Winner } & Non-winner & $\mathrm{N}$ \\
& No Controls & With Controls & Mean & \\
\hline Lives in Ahmedabad in 2007 & -0.01 & 0.00 & 0.97 & 443 \\
Ward level population density & $(0.02)$ & $(0.02)$ & {$[0.18]$} & \\
& $-7375.10^{* * *}$ & $-7902.76^{* * *}$ & 29802.07 & 386 \\
Urbanicity Index & $(1432.47)$ & $(1412.91)$ & {$[10641.24]$} & \multirow{2}{*}{4} \\
& $-0.34^{* * *}$ & $-0.36^{* * *}$ & -0.01 & 443 \\
Amenities Index & $(0.07)$ & $(0.07)$ & {$[0.61]$} & \\
& $0.20^{* * *}$ & $0.21^{* * *}$ & -0.00 & 443 \\
Total value of housing improvements made (INR & $(0.05)$ & $(0.05)$ & {$[0.46]$} & \\
1000s) & -3.94 & -2.29 & 27.94 & 443 \\
Chose current location to be near family/friends & $(4.13)$ & $(4.00)$ & {$[58.51]$} & \\
& $-0.11^{* *}$ & $-0.09^{*}$ & 0.33 & 418 \\
Chose current location for resources & $(0.05)$ & $(0.05)$ & {$[0.47]$} & \\
& $-0.09^{*}$ & $-0.12^{* *}$ & 0.29 & 418 \\
Chose current location for price & $(0.05)$ & $(0.05)$ & {$[0.46]$} & \\
& $0.26^{* * *}$ & $0.25^{* * *}$ & 0.09 & 418 \\
Years lived in house to be close to family/friends & $(0.05)$ & $(0.05)$ & {$[0.28]$} & \\
& $-2.13^{* * *}$ & $-1.86^{* * *}$ & 6.30 & 442 \\
Years lived in house to be close to resources & $(0.70)$ & $(0.72)$ & {$[7.38]$} & \\
& $-1.69^{* * *}$ & $-2.21^{* * *}$ & 4.44 & 442 \\
Mid price of houses in area according to real & $(0.63)$ & $(0.65)$ & {$[6.79]$} & \\
estate agent (INR 1000s) & 119.73 & 192.64 & 591.69 & 109 \\
\hline \hline
\end{tabular}

1. Each row of Winner columns reports the coefficient from an OLS regression where the explanatory variable is whether the respondent won the lottery. Robust SE in ( ), standard deviations in [ ]. ${ }^{*} p<0.10,{ }^{* *} p<0.05,{ }^{* * *} p<0.01$

2. The set of controls is the same as in Table II.

3. Ward-level population density was obtained from Census data in 2001, and was only avaible for households still living in Ahmedabad in 2007.

4. The Urbanicity Index consists of miles from house to city center, number of houses in the neighborhood, and minutes walking to nearest hospital and school.

5. The Amenities Index consists of whether the participant could walk outside at night up to 10 PM, whether the house had a durable wall, roof, and floor; and whether they had a private toilet, a separate kitchen, and water tap in the house.

6. Choosing a house for its resources includes the following reasons: to be close to a school, work, for its location or for the area and neighbors. 
Table IV: Economic Well-Being

\begin{tabular}{|c|c|c|c|c|}
\hline & \multicolumn{2}{|c|}{ Winner } & \multirow{2}{*}{$\begin{array}{l}\text { Non-winner } \\
\text { Mean }\end{array}$} & \multirow[t]{2}{*}{$\mathrm{N}$} \\
\hline & No Controls & With Controls & & \\
\hline \multicolumn{5}{|l|}{ Panel A - Income \& Wealth } \\
\hline Adult labor supply index & $\begin{array}{l}-0.04 \\
(0.08)\end{array}$ & $\begin{array}{c}-0.04 \\
(0.08)\end{array}$ & $\begin{array}{c}0.00 \\
{[0.71]}\end{array}$ & 414 \\
\hline Adult labor supply cost index & $\begin{array}{c}0.13 \\
(0.10)\end{array}$ & $\begin{array}{c}0.11 \\
(0.10)\end{array}$ & $\begin{array}{l}-0.01 \\
{[0.71]}\end{array}$ & 414 \\
\hline Participant currently rolls beedis & $\begin{array}{l}-0.03 \\
(0.05)\end{array}$ & $\begin{array}{l}-0.03 \\
(0.05)\end{array}$ & $\begin{array}{c}0.75 \\
{[0.43]}\end{array}$ & 414 \\
\hline $\begin{array}{l}\text { Total household income (INR 100s per } \\
\text { month) }\end{array}$ & $\begin{array}{l}-2.93 \\
(3.16)\end{array}$ & $\begin{array}{l}-3.22 \\
(3.18)\end{array}$ & $\begin{array}{l}42.05 \\
{[27.22]}\end{array}$ & 414 \\
\hline Participant income (INR 100s per month) & $\begin{array}{l}-0.52 \\
(0.56)\end{array}$ & $\begin{array}{l}-0.66 \\
(0.55)\end{array}$ & $\begin{array}{l}4.55 \\
{[4.03]}\end{array}$ & 414 \\
\hline Husband income (INR 100s per month) & $\begin{array}{l}-0.86 \\
(1.52)\end{array}$ & $\begin{array}{l}-0.73 \\
(1.55)\end{array}$ & $\begin{array}{c}10.83 \\
{[13.36]}\end{array}$ & 414 \\
\hline Income from sons (INR 100s per month) & $\begin{array}{l}-1.75 \\
(2.64)\end{array}$ & $\begin{array}{l}-2.13 \\
(2.67)\end{array}$ & $\begin{array}{l}22.95 \\
{[24.72]}\end{array}$ & 414 \\
\hline $\begin{array}{l}\text { Income from daughters (INR 100s per } \\
\text { month) }\end{array}$ & $\begin{array}{c}0.58 \\
(0.51)\end{array}$ & $\begin{array}{c}0.57 \\
(0.49)\end{array}$ & $\begin{array}{l}1.19 \\
{[3.83]}\end{array}$ & 414 \\
\hline $\begin{array}{l}\text { Net housing revenue since } 1993 \text { (INR } \\
\text { 1000s) }\end{array}$ & $\begin{array}{c}7.12 \\
(6.16)\end{array}$ & $\begin{array}{l}10.33 \\
(6.30)\end{array}$ & $\begin{array}{l}-13.14 \\
{[70.43]}\end{array}$ & 439 \\
\hline Asset Index & $\begin{array}{l}-0.00 \\
(0.04)\end{array}$ & $\begin{array}{c}0.01 \\
(0.04)\end{array}$ & $\begin{array}{l}-0.00 \\
{[0.41]}\end{array}$ & 443 \\
\hline \multicolumn{5}{|l|}{ Panel B - Human Capital } \\
\hline Fertility since 1987 & $\begin{array}{l}-0.13 \\
(0.14)\end{array}$ & $\begin{array}{l}-0.08 \\
(0.14)\end{array}$ & $\begin{array}{c}1.08 \\
{[1.35]}\end{array}$ & 443 \\
\hline Health Index & $\begin{array}{l}-0.01 \\
(0.07)\end{array}$ & $\begin{array}{l}-0.03 \\
(0.07)\end{array}$ & $\begin{array}{l}-0.00 \\
{[0.56]}\end{array}$ & 443 \\
\hline Child's years schooling completed & $\begin{array}{l}-0.51 \\
(0.40)\end{array}$ & $\begin{array}{l}-0.17 \\
(0.35)\end{array}$ & $\begin{array}{l}7.54 \\
{[3.51]}\end{array}$ & 1491 \\
\hline $\begin{array}{l}\text { Child's mean home-school transport cost } \\
\text { for most recent school (INR per day) }\end{array}$ & $\begin{array}{l}-0.19 \\
(1.09)\end{array}$ & $\begin{array}{c}0.74 \\
(1.06)\end{array}$ & $\begin{array}{c}2.76 \\
{[10.34]}\end{array}$ & 1041 \\
\hline
\end{tabular}

1. Each row of Winner columns reports the coefficient from an OLS regression where the explanatory variable is whether the respondent won the lottery. Robust SE in ( ), standard deviations in [ ]. ${ }^{*} p<0.10,{ }^{* *} p<0.05,{ }^{* * *} p<0.01$

2. Controls same as Table II. Regressions at the child level include child's gender as a control and participant-clustered SEs.

3. The Adult Labor Supply Index consists of whether the participant and husband work, number of hours worked, and whether participant has a part-time job. The Adult Labor Supply Cost Index consists of whether participant has a job outside the home, and for the husband, whether his job required a commute, minutes taken to get to work, and money spent to go to work. 4. Income questions exclude deceased and incapacitated participants, whose families were not asked these questions.

The sample for questions about husbands and children excludes 6 lottery participants who were never married.

The sample for participant's work also excludes deceased and incapacitated participants. The sample for husband's work history excludes 63 participants whose husbands have not been in the household since before the lottery.

5. Net housing revenue was calculated from the amount reported made from selling or leasing houses minus the reported amount paid on mortgages and leases.

6. The Asset Index consists of whether the household owns each of the following: color television, motorcycle, rickshaw, bicycle, kerosene stove, ceiling fan, almirah, radio and mobile phone.

7. The Health Index consists of participant's current health status, months during which participant had health problems, participant has a persistent health problem, number of disease symptoms experienced by the participant in the last 30 days, and number of physical activities with which the respondent has health difficulties, as well as if anyone in the household required medical treatment in the past year, number of times someone was sick in past year, if anyone had a health problem, number of breathing/coughing/backache problems participant has, if husband has breathing/coughing/backache/alcoholism problems, and if any child has beedi-related health problem. 
Table V: Social Capital

\begin{tabular}{|c|c|c|c|c|}
\hline & \multicolumn{2}{|c|}{ Winner } & \multirow{2}{*}{$\begin{array}{c}\text { Non-winner } \\
\text { Mean }\end{array}$} & \multirow[t]{2}{*}{$\mathrm{N}$} \\
\hline & No Controls & With Controls & & \\
\hline \multicolumn{5}{|l|}{ Panel A - Informal Insurance } \\
\hline $\begin{array}{l}\text { Has someone for any of four lending and } \\
\text { borrowing categories }\end{array}$ & $\begin{array}{c}-0.09^{* *} \\
(0.04)\end{array}$ & $\begin{array}{c}-0.10^{* *} \\
(0.04)\end{array}$ & $\begin{array}{c}0.93 \\
{[0.26]}\end{array}$ & 414 \\
\hline $\begin{array}{l}\text { Amount of informal transfer received in event } \\
\text { of shock (INR) }\end{array}$ & $\begin{array}{c}-70.77^{* *} \\
(28.52)\end{array}$ & $\begin{array}{c}-79.05^{* *} \\
(32.03)\end{array}$ & $\begin{array}{c}70.77 \\
{[500.88]}\end{array}$ & 403 \\
\hline $\begin{array}{l}\text { If has someone from one of the four lending } \\
\text { or borrowing categories, years known }\end{array}$ & $\begin{array}{c}-3.25^{* * *} \\
(1.24)\end{array}$ & $\begin{array}{c}-2.89^{* *} \\
(1.27)\end{array}$ & $\begin{array}{l}20.04 \\
{[11.72]}\end{array}$ & 374 \\
\hline $\begin{array}{l}\text { Percent of people lend/borrow with who are } \\
\text { from same caste }\end{array}$ & $\begin{array}{l}-0.03 \\
(0.06)\end{array}$ & $\begin{array}{l}-0.00 \\
(0.05)\end{array}$ & $\begin{array}{c}0.65 \\
{[0.45]}\end{array}$ & 375 \\
\hline \multicolumn{5}{|l|}{ Panel B - Social interaction } \\
\hline $\begin{array}{l}\text { Miles from child's house to mother's in } \\
\text { Ahmedabad (if } 16 \text { and over) }\end{array}$ & $\begin{array}{c}0.66^{* * *} \\
(0.18)\end{array}$ & $\begin{array}{c}0.63^{* * *} \\
(0.14)\end{array}$ & $\begin{array}{c}0.71 \\
{[1.52]}\end{array}$ & 1159 \\
\hline $\begin{array}{l}\text { Participant sees this child at least monthly } \\
\text { (if } 16 \text { and over) }\end{array}$ & $\begin{array}{l}-0.04^{*} \\
(0.03)\end{array}$ & $\begin{array}{l}-0.03 \\
(0.03)\end{array}$ & $\begin{array}{c}0.92 \\
{[0.27]}\end{array}$ & 1278 \\
\hline Ever socialize with neighbor & $\begin{array}{l}0.03^{* *} \\
(0.01)\end{array}$ & $\begin{array}{l}0.03^{* *} \\
(0.01)\end{array}$ & $\begin{array}{l}0.95 \\
{[0.21]}\end{array}$ & 1209 \\
\hline $\begin{array}{l}\text { Neighbor is same caste (same religion if } \\
\text { Muslim) }\end{array}$ & $\begin{array}{c}-0.08^{* *} \\
(0.04)\end{array}$ & $\begin{array}{c}-0.08^{* *} \\
(0.04)\end{array}$ & $\begin{array}{c}0.34 \\
{[0.47]}\end{array}$ & 1220 \\
\hline Someone in neighbor's house rolls beedis & $\begin{array}{l}0.12^{* *} \\
(0.05)\end{array}$ & $\begin{array}{c}0.12^{* * *} \\
(0.04)\end{array}$ & $\begin{array}{c}0.29 \\
{[0.45]}\end{array}$ & 1210 \\
\hline \multicolumn{5}{|l|}{ Panel C - Collective Action } \\
\hline $\begin{array}{l}\text { Neighbors have worked together to solve a } \\
\text { common problem in the last three years }\end{array}$ & $\begin{array}{c}0.19^{* * *} \\
(0.05)\end{array}$ & $\begin{array}{c}0.17^{* * *} \\
(0.05)\end{array}$ & $\begin{array}{c}0.19 \\
{[0.39]}\end{array}$ & 414 \\
\hline $\begin{array}{l}\text { Days spent working together in previous year } \\
\text { on most recent project }\end{array}$ & $\begin{array}{l}2.92^{* *} \\
(1.39)\end{array}$ & $\begin{array}{l}2.73^{* *} \\
(1.37)\end{array}$ & $\begin{array}{c}1.66 \\
{[5.67]}\end{array}$ & 413 \\
\hline $\begin{array}{l}\text { Amount spent in previous year on most recent } \\
\text { project (INR) }\end{array}$ & $\begin{array}{l}221.75^{* *} \\
(103.96)\end{array}$ & $\begin{array}{l}205.94^{*} \\
(110.06)\end{array}$ & $\begin{array}{c}291.69 \\
{[1104.25]}\end{array}$ & 409 \\
\hline $\begin{array}{l}\text { Most or all people in the neighborhood } \\
\text { contributed money for the project }\end{array}$ & $\begin{array}{c}0.20^{* * *} \\
(0.05)\end{array}$ & $\begin{array}{c}0.18^{* * *} \\
(0.05)\end{array}$ & $\begin{array}{c}0.17 \\
{[0.38]}\end{array}$ & 410 \\
\hline Attended any Beedi Union meeting in past year & $\begin{array}{c}-0.22^{* * *} \\
(0.05)\end{array}$ & $\begin{array}{c}-0.18^{* * *} \\
(0.05)\end{array}$ & $\begin{array}{c}0.47 \\
{[0.50]}\end{array}$ & 443 \\
\hline
\end{tabular}

1. Each row of Winner columns reports the coefficient from an OLS regression where the explanatory variable is whether the respondent won the lottery. Robust SE in ( ), standard deviations in [ ]. ${ }^{*} p<0.10,{ }^{* *} p<0.05,{ }^{* * *} p<0.01$

2. Controls same as Table II. Regressions at the child level include the child's gender as a control and participant-clustered SEs. The immediate neighbor from same caste outcome excludes the caste and religion covariates. 3. Sample excludes participants who are dead or incapacitated. For immediate neighbors, sample consists of the four neighbors living left, right, front, and behind participants. 1220 neighbors reported. The number of neighbors was balanced across winners and non-winners. For these regressions, standard errors are clustered at the participant level.

4. "Has someone for lending or borrowing needs" combines whether they have (i) someone to borrow Rs. 50 from, (ii) someone you would lend Rs. 50 (iii) someone from whom you can borrow rice or cooking oil, and (iv) someone from whom you could borrow Rs. 500 for a health emergency.

5. Recent shocks asked about are communal riots, earthquake, and outbreak of the chikangunya virus. 
Table VI: Heterogeneity of Impact for Winners

\begin{tabular}{|c|c|c|c|c|}
\hline & $\begin{array}{l}\text { Lives in } \\
\text { Colony A }\end{array}$ & $\begin{array}{l}\text { Used to Live } \\
\text { in Colony A }\end{array}$ & $\begin{array}{c}\text { Mean if never } \\
\text { lived in Colony } \mathrm{A}\end{array}$ & $\mathrm{N}$ \\
\hline \multicolumn{5}{|l|}{ Panel A - Housing and Income } \\
\hline Years lived in Colony A & $\begin{array}{c}12.08^{* * *} \\
(0.67)\end{array}$ & $\begin{array}{c}7.19^{* * *} \\
(0.70)\end{array}$ & $\begin{array}{c}0.00 \\
{[0.00]}\end{array}$ & 105 \\
\hline Chose current location for price & $\begin{array}{c}0.79^{* * *} \\
(0.08)\end{array}$ & $\begin{array}{l}-0.03 \\
(0.07)\end{array}$ & $\begin{array}{l}0.09 \\
{[0.29]}\end{array}$ & 98 \\
\hline Urbanicity Index & $\begin{array}{c}-0.75^{* * *} \\
(0.12)\end{array}$ & $\begin{array}{r}-0.29^{* *} \\
(0.14)\end{array}$ & $\begin{array}{l}0.01 \\
{[0.52]}\end{array}$ & 105 \\
\hline Amenities Index & $\begin{array}{c}0.09 \\
(0.09)\end{array}$ & $\begin{array}{l}-0.04 \\
(0.10)\end{array}$ & $\begin{array}{c}0.19 \\
{[0.42]}\end{array}$ & 105 \\
\hline $\begin{array}{l}\text { Total monthly household income (INR 100s per } \\
\text { month) } \\
\text { Panel B - Social Interactions }\end{array}$ & $\begin{array}{c}0.72 \\
(6.43)\end{array}$ & $\begin{array}{l}-3.02 \\
(7.20)\end{array}$ & $\begin{array}{l}39.84 \\
{[26.75]}\end{array}$ & 96 \\
\hline $\begin{array}{l}\text { Neighbors have worked together to solve a } \\
\text { common problem in the last three years }\end{array}$ & $\begin{array}{c}0.57^{* * *} \\
(0.10)\end{array}$ & $\begin{array}{c}0.07 \\
(0.10)\end{array}$ & $\begin{array}{c}0.16 \\
{[0.37]}\end{array}$ & 96 \\
\hline Attended beedi union meeting in past year & $\begin{array}{l}-0.15 \\
(0.10)\end{array}$ & $\begin{array}{l}-0.05 \\
(0.11)\end{array}$ & $\begin{array}{c}0.31 \\
{[0.47]}\end{array}$ & 105 \\
\hline Someone in neighbor's house rolls beedis & $\begin{array}{c}0.45^{* * *} \\
(0.08)\end{array}$ & $\begin{array}{l}-0.08 \\
(0.08)\end{array}$ & $\begin{array}{c}0.25 \\
{[0.43]}\end{array}$ & 291 \\
\hline $\begin{array}{l}\text { Participant sees this child at least monthly } \\
\text { (if } 16 \text { and over) }\end{array}$ & $\begin{array}{l}-0.09^{*} \\
(0.05)\end{array}$ & $\begin{array}{l}-0.04 \\
(0.05)\end{array}$ & $\begin{array}{c}0.93 \\
{[0.26]}\end{array}$ & 290 \\
\hline $\begin{array}{l}\text { Miles from child's house to mother's in } \\
\text { Ahmedabad (if } 16 \text { and over) }\end{array}$ & $\begin{array}{l}0.71^{*} \\
(0.43)\end{array}$ & $\begin{array}{l}-0.23 \\
(0.42)\end{array}$ & $\begin{array}{l}1.15 \\
{[1.79]}\end{array}$ & 254 \\
\hline Panel C - Informal Insurance & & & & \\
\hline $\begin{array}{l}\text { Has someone for any of four lending and } \\
\text { borrowing categories }\end{array}$ & $\begin{array}{l}0.22^{* *} \\
(0.09)\end{array}$ & $\begin{array}{c}0.12 \\
(0.11)\end{array}$ & $\begin{array}{c}0.72 \\
{[0.46]}\end{array}$ & 96 \\
\hline $\begin{array}{l}\text { If has someone from one of the four lending } \\
\text { or borrowing categories, years known }\end{array}$ & $\begin{array}{l}-3.44 \\
(2.51)\end{array}$ & $\begin{array}{l}-4.38 \\
(2.89)\end{array}$ & $\begin{array}{l}19.55 \\
{[10.09]}\end{array}$ & 80 \\
\hline $\begin{array}{l}\text { Percent of people lend/borrow with who are } \\
\text { from same caste }\end{array}$ & $\begin{array}{c}-0.28^{* *} \\
(0.12)\end{array}$ & $\begin{array}{l}-0.07 \\
(0.12)\end{array}$ & $\begin{array}{l}0.75 \\
{[0.41]}\end{array}$ & 80 \\
\hline
\end{tabular}

1. We report OLS regressions with robust SE in ( ), standard deviations in [ ]. ${ }^{*} p<0.10,{ }^{* *} p<0.05,{ }^{* * *} p<0.01$

2. For regressions at the child level and the neighbor level standard errors are clustered at the participant level. 
Figure I: Years Spent in Colony A (only Winners)

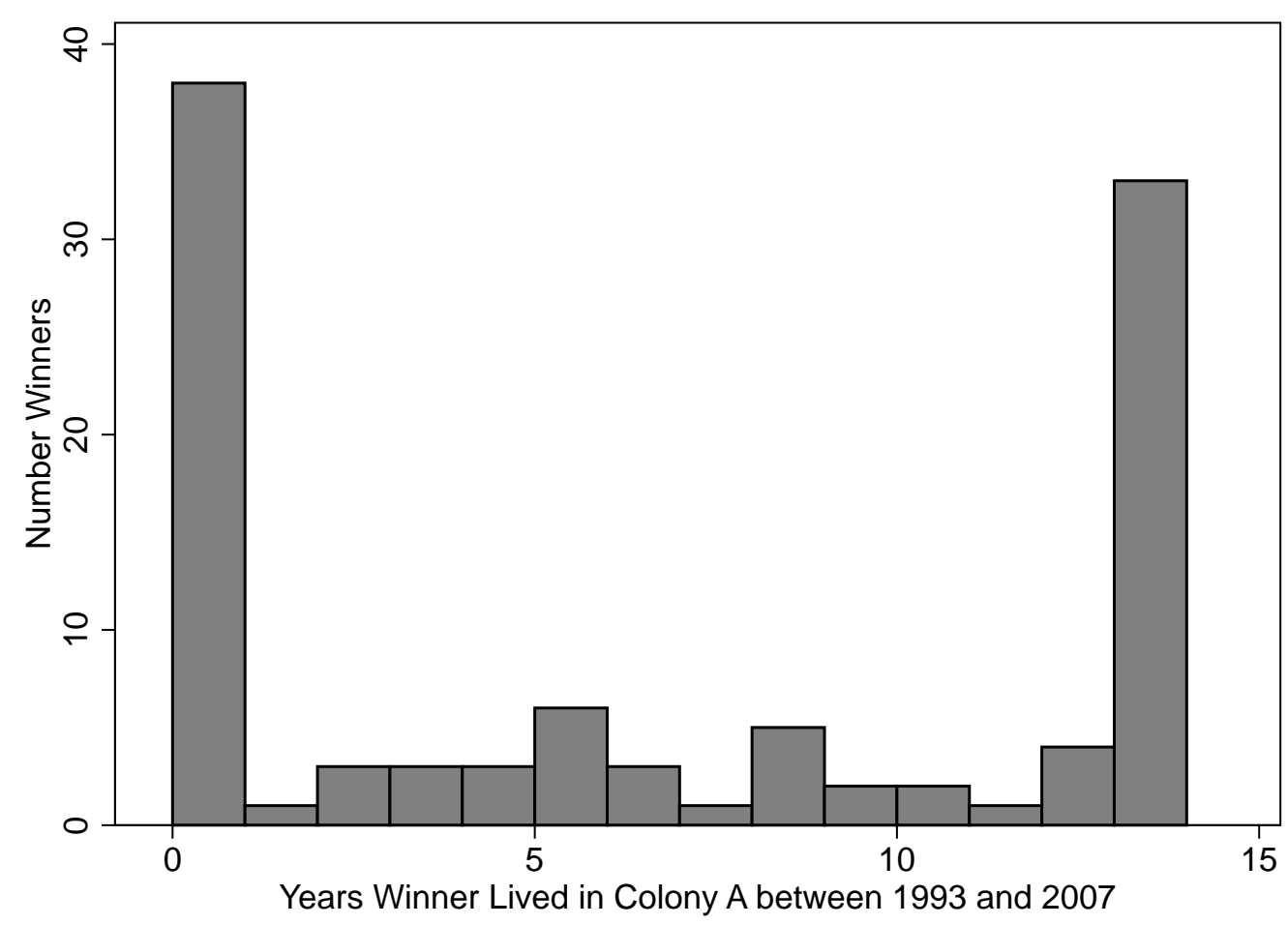


Figure II: Housing Locations 1987

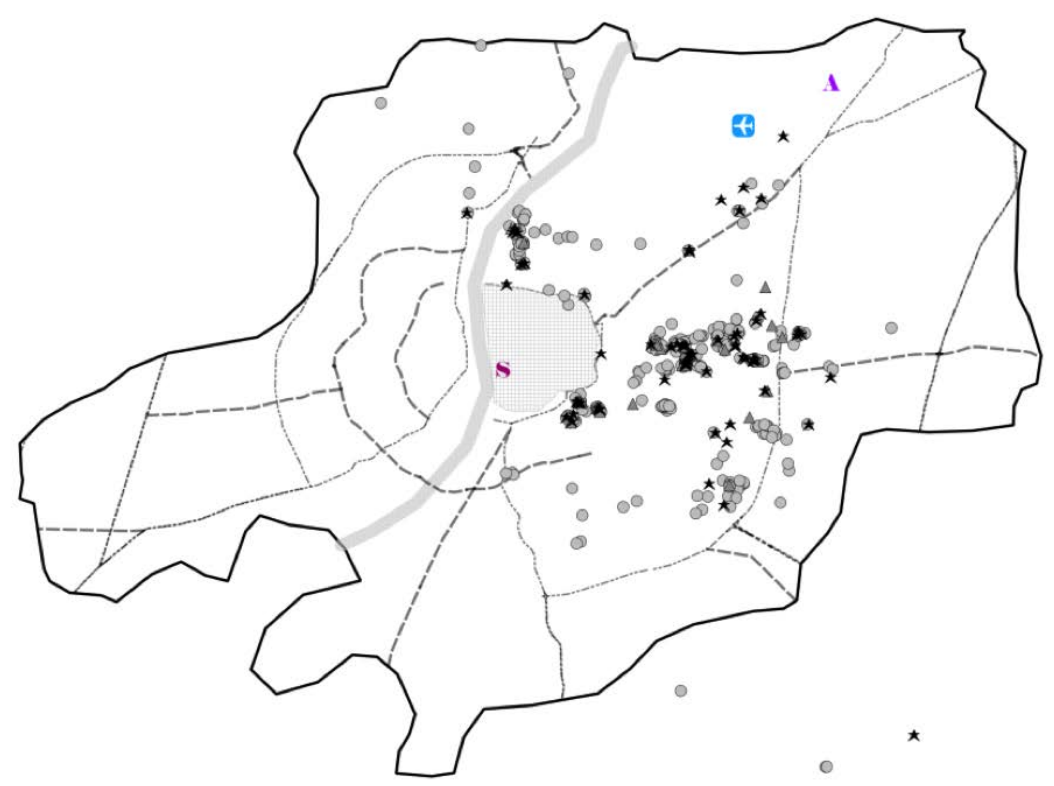

Figure III: Housing Locations 2007

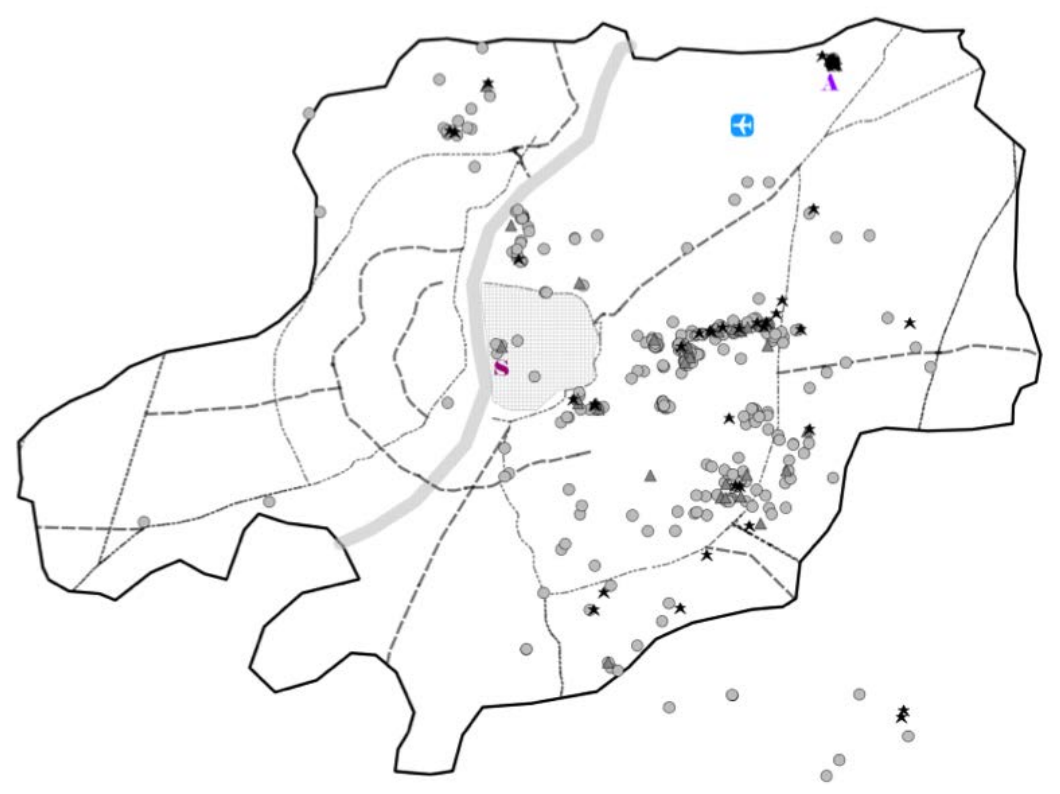

\footnotetext{
Legend

* Winner - family moved to Colony A

$\Delta$ Winner - never moved to Colony A

- Non-winner

Landmarks

(B) Airport

A Colony $\mathrm{A}$

s SEWA Union Headquarters Old City
} 